\title{
Changes in the quality of kefir for baby food from different manufacturers during storage
}

\author{
(C) Yulia V. Shcherbakova, ${ }^{*+}$ Farida Yu. Ahmadullina, ${ }^{*}$ \\ Egor K. Rastegaev, and Svetlana M. Gunicheva \\ Department of Industrial Biotechnology. Kazan National Research Technological University. \\ K. Marks St., 72. Kazan, 420015. Republic of Tatarstan. Russia. \\ Phone:+7 (843)231-89-19.E-mail: balakirevajulia3@mail.ru
}

\begin{abstract}
*Supervising author; ${ }^{+}$Corresponding author
Keywords: kefir, various manufacturers, lipid peroxidation, titratable acidity.
\end{abstract}

\begin{abstract}
In this article was stydied the influence of the shelf life of kefir for baby food on their quality, estimated by the titrated acidity and intensity of lipid peroxidation process. The last was determined by the change in the concentration of compounds reacting with thiobarbituric acid. Were researched Children's kefir of brands "Adventures of Jovi", "For kids", "Agusha", fat content of 2.5\% and 3.2\% manufacturers of JSC "lactis", JSC "Zelenodolsk milk processing combine" and LLC "Wimm bill Dann". For these samples of fermented milk products for baby food is characterized by different declared shelf life, equal to 6, 15, 9 and 15 days, respectively, which serves as indirect evidence of differences in the methods of their production. The control period of research took into account both the shelf life of the product, declared by the manufacturer, and the period of time a week after its end. This allows, in our opinion, both to assess the impact of the conditions of production of commodity products on its, and it is possible to assess the level of safety of the analyzed kefir in the declared shelf life and, thus, to identify the best brand. The results were compared with data on the integrated antioxidant activity of the studied fermented milk products. Their values were obtained earlier by coulometric titration with electrogenated bromine, which allows to cover the largest number of antioxidants present in the control products at the time of the research. As a result of the comparative analysis it is shown, that children's kefir, the brand " for kids" in the declared shelf life of the manufacturer, is characterized by a lower content of secondary products of lipid peroxidation, causing rancidity of kefirs, while its antioxidant activity is the highest among the studied samples of kefirs for baby food. The results suggest that the technology for producing baby kefir of this brand is optimal, providing high quality, which is very important for the growing up body.
\end{abstract}

\section{References}

[1] Yu.V. Shcherbakova. Dissertation. Influence of heat treatment on components of antioxidant system of milk and its integral antioxidant activity. Moscow. 2011. 145p. (russian)

[2] GOST 3624-92. Milk and dairy products. Titrimetric methods for the determination of acidity.

[3] Methodological position on the study of free radical oxidation processes and the antioxidant defense system of the body. comp. M.I. Retsky, S.V. Shabunin, G.N. Bliznetsova [et al.]; FSEI HPE Voronezh State University. Voronezh. 2010. 70p. (russian)

[4] A.I. Kostyuk, D.A. Kotova, A.D. Demidovich, A.S. Panova, I.V. Kelmanson, V.V. Belousov, D.S. Bilan. Change of key parameters of lipid metabolism in rat brain tissues in permanent ischemia. Bulletin of the Russian state medical University. 2019. No.1. P.50-57. (russian)

[5] Nguyen Thien. Graduate work. Integral antioxidant activity, kefir for baby food, shelf life, coulometric titration. KNRTU. 2014. P.29. (russian)

[6] Utochkina Elena Alexandrovna, Reshetnik Ekaterina Ivanovna. Influence of arabinogalactan on microbiological indicators and storage ability of fermented dairy products. Food Engineering and Technology. 2012. No.4. P.1-4. (russian)

[7] Michael G Ganzle. Lactic metabolism revisited: metabolism of lactic acid bacteria in food fermentations and food spoilage. Current opinion in food science. 2015. P.106-117.

[8] K.R. Sagdeeva, A.I. Azizova, L.R. Muhametzyanova, V.S. Devyatko, V.V. Zaharov, Yu.V. Sherbakova, and F.Yu. Ahmadullina. Antioxidant activity of kefir. Butlerov Communications. 2015. Vol.41. No.3. P.152-155. DOI: 10.37952/ROI-jbc-01/15-41-3-152 